\title{
An Analysis of Suicides in Telangana, India
}

\author{
Gopala S Poduri
}

\begin{abstract}
Background: Suicide is a major public health hazard, and there were no reports from the new state of Telangana.

Aim: To analyze the suicides of Telangana from its formation year.

Meterials and methods: Information relating to suicides was obtained from sources and under the RTI Act from the office of Director General of Police, Telangana state. The data obtained relates to a total number of suicides, age-wise, sex-wise, mode, reason, education, profession, socioeconomic status, community, and caste for Telangana and Hyderabad city separately for the years 2014 to 2016 . The data were analyzed comparing various parameters between Hyderabad and Core Telangana using basic statistics.

Results: The rates were above in Telangana and below in Hyderabad in comparison to the national average. There was a decline in the thirdyear. There was a preponderance of men, married, educated, and quick, sure and violent methods used. Open category (OC) castes and other than OC castes were over-represented in Hyderabad and Telangana, respectively.

Conclusion: There is an urgent need to analyze suicides at micro-level-Mandal and district.

Keywords: Caste, Core Telangana, Hyderabad, Suicide rate.

Indian Journal of Private Psychiatry (2019): 10.5005/jp-journals-10067-0025
\end{abstract}

\section{An Analysis of Telangana Suicides}

Telangana is the 28th and the youngest state of the Indian Republic. It was formed after bifurcation of erstwhile Teluguspeaking Andhra Pradesh in 2014. The state has a sex ratio of 988 (higher than the national average of 943 in 2011). The government conducted an Intensive Household Survey (Samagra Kutumba Survey) on 19.08.2014 throughout the state. The total population was 363.03 lakh. With $66.46 \%$ of literacy rate, the state has a lower rate than the national average of 72.99. Earlier, there was a spate of suicides among wavers and later farmers in the state. As the new state suicide data did not find a place in Indian psychiatric literature, an effort was made to analyze suicides from the area for the years 2014 to 2016 calendar years.

\section{Meterials and Methods}

Information about suicides from sources and under RTI Act, in the office of Director General of Police, Telangana state was obtained for the years from 2014 to 2016. The available data were obtained in Excel format as it appears in National Crime Records Bureau (NCRB) statistics. The data obtained relates to total Telangana and Hyderabad separately, about total number of suicides, age-wise, sex-wise, mode, reason, education, profession, socioeconomic status. The number of suicides from Hyderabad was deducted from total to obtain Core Telangana suicides. Population data was collected from appropriate sources. ${ }^{2}$ The classification of obtained data was slightly modified to make a meaningful analysis. For example, in educational status, primary, middle, matriculate, and secondary levels were clubbed to come under school education; diploma and professionals were under professionals. Like-wise under profession, daily wage earners, self-employed earners, Professional/salaried earners, and pensioners were clubbed as earners. For method, poisoning and consuming pills were clubbed as soft methods, while jumping, coming under running vehicles, touching electric wire, drowning, fire/self-immolation, firearms, and hanging were considered under hard methods. Causes were
Department of Psychiatry, Yashoda Super-Speciality Hospital Hyderabad, Telangana, India

Corresponding Author: Gopala S Poduri, Department of Psychiatry, Yashoda Super-Speciality Hospital, Hyderabad, Telangana, India, Phone: +91 8179136510, e-mail: gopalasarmapoduri@hotmail.com

How to cite this article: Poduri GS. An Analysis of Suicides in Telangana. Ind J Priv Psychiatry 2019;13(1):1-3.

Source of support: Nil

Conflict of interest: None

considered as failure in examination, illness (illness, drug abuse/ alcoholic addition), family problems (family problems, marriage related issues, impotency/infertility, marriage related issues, sex, physical abuse, illegitimate pregnancy suspected/illicit relation, property dispute), economic (bankruptcy or indebtedness, unemployment, poverty), emotional (ideological causes/ hero worshipping, love affairs, death of a dear person, fall in social reputation, professional/career problem), cause not known and other causes, social status as unmarried, married, married but permanently/temporarily single-(widowed/widower, divorcee, separated), others, status not known. Years of life lost was computed by deducting an average of the age group from life expectancy (for example 30 and above-below 45 years group: (life expectancy of the year- $(30+44 / 2))$.

Suicides for the three years were clubbed to get a comprehensive view where needed. The data were compared between Hyderabad and Core Telangana. The data were analyzed using basic statistics.

\section{Results}

In all, there were a total of 28,787 suicides in the three years one suicide every 55 minutes. The corresponding figures were 2,135 one suicide every 12.3 hours in Hyderabad and 3,392 one suicide every 7.7 hours by farmers. Farmers' contribution of $11.8 \%$ of total 
Suicides in Telangana, India

Table 1: Sex-wise break-up of suicides of Hyderabad, Core Telangana and farmers during 2014-2016

\begin{tabular}{|c|c|c|c|c|c|c|c|c|c|}
\hline \multirow[b]{2}{*}{ Sex } & \multicolumn{3}{|c|}{2014} & \multicolumn{3}{|c|}{2015} & \multicolumn{3}{|c|}{2016} \\
\hline & Hyderabad & $\begin{array}{l}\text { Core } \\
\text { Telangana }\end{array}$ & Farmers & Hyderabad & $\begin{array}{l}\text { Core } \\
\text { Telangana }\end{array}$ & Farmers & Hyderabad & $\begin{array}{l}\text { Core } \\
\text { Telangana }\end{array}$ & Farmers \\
\hline Male & 510 & 6,159 & 1,115 & 538 & 6,771 & 1,241 & 460 & 5,867 & 572 \\
\hline Female & 231 & 2,723 & 232 & 190 & 2,641 & 159 & 206 & 2,491 & 73 \\
\hline Total & 741 & 8,882 & 1,347 & 728 & 9,412 & 1,400 & 666 & 8,358 & 645 \\
\hline
\end{tabular}

Table 2: Sex-wise distribution of three years suicides of farmers, Hyderabad, Core Telangana and Telangana

\begin{tabular}{lllll}
\hline & \multicolumn{4}{c}{$2014-2016$} \\
\cline { 2 - 5 } Total & $\begin{array}{l}\text { Farmers (a) } \\
\text { (\%) }\end{array}$ & $\begin{array}{l}\text { Hyderabad } \\
\text { (b) }(\%)\end{array}$ & $\begin{array}{l}\text { Core } \\
\text { Telangana }\end{array}$ & $\begin{array}{l}\text { Telangana } \\
\text { Total (c) (\%) }\end{array}$ \\
\hline Male & $2,928(14.4)$ & $1,508(7.4)$ & $18,797(92.6)$ & $20,305(70.5)$ \\
Female & $464(0.1)$ & $627(7.4)$ & $7,855(92.6)$ & $8,482(29.5)$ \\
Total & $3,392(11.8)$ & $2,135(7.4)$ & $26,652(92.6)$ & 28,787 \\
$\%$ & 11.78 & 7.42 & 92.58 & 100 \\
\hline
\end{tabular}

suicides was higher in comparison to Hyderabad's 7.4\%. In all, the total suicides committed were 9,623 (male-6,669; female-2,954) in 2014; 10,140 (male-7,309; female-2,831) in 2015; and 9,024 (male-6,327; female-2,697) in 2016. The crude rates of suicide were $25.9,26.9$, and 23.4 for 2014, 2015, and 2016, respectively. The rates were above the national average. With Core Telangana without melting pot culture Hyderabad, the rates were still higher-36.65, 35.97, and 31.77 showing a declining trend. For Hyderabad, the corresponding rates were below the national average-9.04, 8.18, and 6.5 also showing a declining trend.

Table 1 gives sex-wise break-up of suicides of Hyderabad, Core Telangana and farmers during 2014 to 2016.

Table 2 gives sex-wise distribution of three years suicides of farmers, Hyderabad, Core Telangana, and Telangana.

Years of presumed life lost (YPLL) for 2014, 2015, and 2016 due to suicides in Telangana were 2,30,501, 2,41,229, and 2,09,803, respectively.

Persons above 60 years constituted $9.5,6.1$, and $10.7 \%$ of farmers, Hyderabad, and Telangana respectively.

Table 3 gives sex-wise distribution of the highest and lowest $\%$ of various parameters for suicides of Hyderabad, Core Telangana and Telangana.

Disproportionately more Muslims committed suicide in Hyderabad in the three-year period in comparison with Core Telangana $(19.7 \% \times 6.9 \%)$. The total suicide contribution by OBC, SC, and ST was four times that of the general category in Core Telangana. In comparison in Hyderabad, the general category contributed to more than half (51.4\%).

More than $90 \%$ of the farmers were married and were in the age group 30 to 45 with no education and committed suicide for economic reasons.

\section{Discussion}

The problems with studies on suicides and consequent interpretations are many. It starts with data gathering. Suicide being a sensitive issue, it is grossly under-reported. Adding to this is the computation of the population for a particular year, which depends on the method, source used. One has to necessarily depend on NCRB statistics (which are a sum of state crime records bureau (SCRB) the source of present data) for comparison purposes. The discrepancy in rates from NCRB was due to the population taken for computation. As the data in this way from the concerned state, in case of any deviation from the NCRB statistics, the state data should be taken as correct.

The increasing number of psychiatrists might have contributed to the reduction in suicides in 2016. As the number increased more in Hyderabad, the reduction is more there. As the psychiatrists are spreading on to other places in the state, the decline was seen in the third-year. This may not be the whole reason. Nevertheless, the drastic reduction in suicides should be viewed with caution and probed.

The predominance of male suicides reflects the stressors of men, due to conventional patriarchal society and excessive consumption of alcohol as the second-highest revenue generator in Telangana is the excise department. The excise angle should be taken seriously, notwithstanding very low drug abuse/alcohol addiction as the cause was given. The reason for far fewer farmer women committing suicides than Hyderabad women maybe a reflection on their adaptability that is inherent to natives that comes with constant stresses depending on nature and developing methods to combat them.

The maximum number of suicides in 30 years to 45 years age group is reflective of the stress-prone period when financial and family responsibilities are at a peak in a traditional and conventional family.

The greater proportion of OC (general) suicides in Hyderabad may be due to the feeling of alienation and consequent frustration due to a gross mismatch between expectations and reality of employment, education, opportunities, etc. The disproportionately higher Muslim suicides in Hyderabad may also be due to similar reasons and higher population of that community.

Even with all-round condemnation of caste and remedial supportive measures taken, the non-OC groups in nonmetro areas seem to be under stress, as evidenced by more suicides among them in Telangana and Core Telangana. Since Hyderabad happens to be a cosmopolitan and multicultural, the caste system may not be much. Here the greater $\mathrm{OC}$ suicides may be a reflection of stress and frustration due to restricted openings in education and employment for them.

School or college education does not seem to be a protector. Higher education seems to protect as the least number of suicides were in the professionally educated. Paradoxical is the fact of the reduction of suicides with a progressive decline of admissions in professional colleges and consequent closure of many engineering and computer and business education colleges and reduction in suicides. Another point of interest is that no education status is second-highest among the suicides. An in-depth analysis of quality of education and suicide is needed to draw any meaningful conclusion about the relationship between education and suicide. This point should be taken note of by policymakers. 
Suicides in Telangana, India

\begin{tabular}{|c|c|c|c|c|c|c|}
\hline \multirow[b]{2}{*}{ Parameter } & \multicolumn{3}{|c|}{ Highest percentage } & \multicolumn{3}{|c|}{ Lowest percentage } \\
\hline & Hyderabad & Core Telangana & Telangana & Hyderabad & Core Telangana & Telangana \\
\hline Sex & Male 71 & Male 70 & Male 70 & Female 29 & Female 29 & Female 30 \\
\hline Age & $\begin{array}{l}30 \text { and above- } \\
\text { below } 45 \text { years } 36.3\end{array}$ & $\begin{array}{l}30 \text { and above- } \\
\text { below } 45 \text { years } 3.8\end{array}$ & $\begin{array}{l}30 \text { and above- } \\
\text { below } 45 \text { years } 34.0\end{array}$ & below 14 years 1.0 & below 14 years 0.3 & below 14 years 0.3 \\
\hline Education & School 39.3 & School 48.6 & School 47.9 & Professional 3.1 & Professional 1.2 & Professional 1.1 \\
\hline Profession & Earners 55.3 & Earners 39.9 & Earners 41.0 & Students 7.7 & $\begin{array}{l}\text { Unemployed } \\
\text { persons } 2.9\end{array}$ & $\begin{array}{l}\text { Unemployed } \\
\text { persons } 3.4\end{array}$ \\
\hline $\begin{array}{l}\text { Means } \\
\text { adopted }\end{array}$ & Violent 64.4 & Violent 55.2 & Violent 55.8 & Non-violent 12.1 & $\begin{array}{l}\text { By other means } \\
8.1\end{array}$ & $\begin{array}{l}\text { By other means } \\
9.2\end{array}$ \\
\hline Causes & $\begin{array}{l}\text { Family, marriage, } \\
\text { sex, etc. } 40.4\end{array}$ & $\begin{array}{l}\text { Family, marriage, } \\
\text { sex, etc. } 23.1\end{array}$ & $\begin{array}{l}\text { Family, marriage, } \\
\text { sex, etc. } 30.2\end{array}$ & $\begin{array}{l}\text { Failure in } \\
\text { examination } 1.8\end{array}$ & $\begin{array}{l}\text { Failure in } \\
\text { examination } 1.1\end{array}$ & $\begin{array}{l}\text { Failure in } \\
\text { examination } 1.2\end{array}$ \\
\hline $\begin{array}{l}\text { Economic } \\
\text { status }\end{array}$ & $\begin{array}{l}\text { Less than Rs. } 1 \\
\text { Lakh } 76.3\end{array}$ & $\begin{array}{l}\text { Less than Rs. } 1 \\
\text { Lakh } 67.0\end{array}$ & $\begin{array}{l}\text { Less than Rs. } 1 \\
\text { Lakh } 67.7\end{array}$ & $\begin{array}{l}\text { Rs. } 10 \text { Lakh and } \\
\text { above } 0.4\end{array}$ & $\begin{array}{l}\text { Rs. } 5 \text { Lakh and } \\
\text { above and less } \\
\text { than Rs. } 10 \text { Lakh } \\
4.4\end{array}$ & $\begin{array}{l}\text { Rs. } 5 \text { Lakh and } \\
\text { above less than } \\
\text { Rs. } 10 \text { Lakh } 4.2\end{array}$ \\
\hline Social status & Married 60.6 & Married 67.1 & Married 67.5 & Divorcee 1.0 & Separated 1.4 & Separated 1.4 \\
\hline Community & $\begin{array}{l}\text { Hindu 75.2, Muslim } \\
19.7\end{array}$ & Hindu 81.1 & Hindu 80.7 & SIKH 0.1 & SIKH 0.2 & SIKH 0.2 \\
\hline Caste & General 51.4 & OBC 49.4 & OBC 48.1 & ST 2.7 & ST 12.3 & ST 11.9 \\
\hline
\end{tabular}

Earners formed the bulk indicating the mismatch between earnings and needs more so in Hyderabad. Students have the least percent in Hyderabad and unemployed in Core and total Telangana. This indicates that notwithstanding stress put on students by parents, educational management, the students somehow were able to face it. The real picture appears to be unemployment.

The method chosen by majority violent with almost immediate death assumed is indicative of the determination of the deceased. The possibility of intervention and avoiding death seems to be not much.

The commonest cause-family-related and maximum number of deceased being married is indicative of strain of the family system is undergoing. This gets aggravated by majority earning less than one lakh. In contrast to some studies, ${ }^{3}$ marriages do not seem to be protective as far as suicide is concerned as also observed by others. ${ }^{4}$ This is a reflection of the institution of marriage in contemporary society.

The almost drastic reduction of suicides in the third-year maybe real or administratively directed to project a rosy picture. This can be answered by a field survey only.

India is a pluralistic society. Even among the same languagespeaking people, there will be differences, depending upon the type of background, customs, type of administration, composition, profession, etc. The two Telugu-speaking states are classical examples of this. Suicide rate in Telangana is more than twice of Andhra Pradesh in 2015. There were many studies in Indian psychiatric literature about suicides highlighting various aspects. Many states, including Telangana, have suicide rates that are higher than the national average. The reasons for this are difficult to fathom and can only be speculative. A look at 2014 and 2015 NCRB $^{5}$ suicide data indicate that Telangana is one of the top contributors. This can only be due to cultural reasons. It is heartening to note the decline in 2016. It could be due to improved facilities like health sector expansion. There is a lack of systematic assessment of the reliability of suicide statistics and the under-reporting of suicide. ${ }^{6}$ The present report is in agreement with it.

A microanalysis at the district level (there are 31 districts) may throw much light on suicides. There are vast differences among these districts from highly developed to poorly developed. ${ }^{7}$ So an analysis at that level correlating with various parameters will be rewarding.

The profile of Telangana suicide is male, school educated, earner, Hindu, other than OC castes, married with family problems who resorts to sure, quick, violent methods to achieve the end.

In conclusion, there is an urgent need to analyze at micro-levelMandal and district.

\section{References}

1. https://www.telangana.gov.in/About/State-Profile.

2. Population of Hyderabad 2017 - Population of India 2017. indiapopulation 2017.in/ population-of-hyderabad-2017.html, Hyderabad Population 2018 (Demographics, Maps,Graphs).

3. Kyung-Sook W, ShinSang S, Sangjin S, et al. Marital status integration and suicide: a meta-analysis and meta-regression. Social Science \& Medicine 2018;197:116-126. Available from: https://doi.org/10.1016/ j.socscimed.2017.11.053.

4. Radhakrishnan R, Andrade C. Suicide: An Indian perspective. Indian J Psychiatry 2012;54(4):304-319. DOI: 10.4103/0019-5545.104793.

5. http://ncrb.gov.in/StatPublications/ADSI/ADSI2015/adsi-2015-fullreport. pdf (accessed on October 20, 2018).

6. Tøllefsen IM, Hem E, Ekeberg $\varnothing$. The reliability of suicide statistics: a systematic review. BMC Psychiatry 2012;12:9. DOI: 10.1186/1471-244X12-9.

7. Hyderabad, RR ahead in per capita income - TELANGANA - The Hindu. Available from: https://www. thehindu.com > Today's Paper > NATIONAL , TELANGANA. 